\title{
Analisis Pengaruh Knowledge Sharing Dalam Penerapan Sistem Manajemen Mutu ISO 9001:2008 Terhadap Kinerja Inovasi Dan Kinerja Karyawan
}

\author{
Fajar Maulana $^{1 *}$, R Andi Sularso ${ }^{2}$, Purnamie Titisari ${ }^{2}$ \\ ${ }^{1}$ Program Magister Manajemen, Fakultas Ekonomi dan Bisnis, Universitas Jember \\ ${ }^{2}$ Fakultas Ekonomi dan Bisnis, Universitas Jember \\ *fajar.07.fm@gmail.com
}

\begin{abstract}
Recently, the sugar industry is facing a very tight market competition. This condition encourages companies to improve quality and competitiveness immediately through improvement of customer satisfaction consistently and continuously. The purpose of this research is to examine and discuss the effect of knowledge sharing in applying ISO 9001:2008 Quality Management System to the performance of employees innovation and performance at Jatiroto Sugar Factory. Data obtained through questionnaires as 130 respondents with proportional stratified random sampling. Data analysis uses The Structural Equation Modelling (SEM). The result of the research shows a significant influence between : 1) knowledge sharing on the implementation of ISO 9001:2008; 2) knowledge sharing on innovation performance, 3) knowledge sharing on employee performance, 4) implementation of ISO 9001:2008 on innovation performance, and 5) implementation of ISO 9001:2008 on employee performance. The indirect effect was found a significant in knowledge sharing on innovation performance through the application of ISO 9001:2008. However, there is no influence of knowledge sharing on employee performance through the application of ISO 9001:2008.
\end{abstract}

Keywords: Employee Performance, ISO 9001:2008, Innovation Performance, Knowledge Sharing,

https://doi.org/10.26905/jmdk.v6i1.2045

\section{PENDAHULUAN}

Indonesia pernah mengalami era kejayaan industri gula pada era tahun 1930an dibawah Pemerintah kolonial Hindia Belanda. Industri yang sudah ada di Indonesia sejak ratusan tahun lalu ini, pernah membawa Indonesia menjadi eksportir gula terbesar kedua di dunia setelah Kuba. Pada saat itu, produksi mencapai sekitar 3 juta ton dengan rendemen sebesar 11\%-13\%, sehingga industri gula mengekspor sebanyak 2,4 juta ton. Setiap tahun, kebutuhan gula nasional terus bertambah seiring pertumbuhan konsumsi masyarakat serta pertumbuhan sektor makanan dan minuman. Di tahun 2016, kebutuhan gula nasional sekitar 5,97 juta ton dengan rincian Gula Kristal Putih (GKP) untuk konsumsi masyarakat sebesar 2,85 juta ton dan Gula Kristal Rafinasi (GKR) untuk industri sebesar 3,12 juta ton, sedangkan prediksi kebutuhan gula nasional di tahun 2017 sebesar 6,17 juta tondan tahun 2018 sebesar 6,39 juta ton (Asosiasi Gula Indonesia, 2016).

Pabrik Gula Jatiroto merupakan salah satu pemain utama dalam persaingan industri gula saat ini yang merupakan pabrik gula terbesar dari sisi kapasitas produksi terpasang 
(KES) di wilayah PTPN XI, yaitu sebesar 7.000 TCD. Pabrik Gula Jatiroto memiliki keunikan khusus yang tidak dimiliki oleh pabrik gula lain, diantaranya memiliki lahan HGU yang merupakan terbesar di Pulau Jawa seluas + 7.000 Ha. Total luas tersebut terdiri dari 5.500 Ha merupakan lahan produktif untuk tanaman tebu dan sisanya sebesar 1.500 Ha digunakan sebagai emplasemen pabrik dan sarana prasarana penunjang proses produksi. Demi menjaga kualitas produk dan pelayanan secara kontinyu serta untuk mengantisipasi tuntutan pelanggan dan pasar, Pabrik Gula Jatiroto berkomitmen melakukan peningkatan kinerja manajemen yaitu dengan menerapkan sistem manajemen mutu ISO 9001:2008 secara konsisten.

Pengetahuan memegang peranan yang penting dalam kemajuan perusahaan. Melalui knowledge sharing semua anggota organisasi dapat membagikan pengalaman terbaiknya dengan lebih mudah, menciptakan ide baru yang segar, serta menghemat banyak waktu untuk memecahkan suatu masalah. Perusahaan tidak dapat menciptakan pengetahuan tanpa tindakan dan interaksi para karyawannya. Knowledge sharing memungkinkan suatu organisasi menghasilkan berbagai ide baru yang digunakan untuk penciptaan inovasi. Hal tersebut bermanfaat untuk pengembangan organisasi dalam menciptakan hal baru yang dihasilkan dari rangsangan, serta menambah pengetahuan dan kemampuan yang ada untuk berinovasi (Firmaiansyah, 2014:128).

Inovasi merupakan suatu gagasan baru yang diterapkan untuk memprakarsai atau memperbaiki suatu produk atau proses dan jasa. Orang yang inovatif ditandai oleh kecenderungannya memperkenalkan gagasan, metode, peralatan, prosedur, produk dan jasa baru yang lebih baik atau lebih bermanfaat (Nasution, 2001:21). Kinerja karyawan adalah hasil yang dicapai oleh karyawan tersebut dalam pekerjaanya berdasar kriteria tertentu yang berlaku pada pekerjaan tertentu. Kinerja karyawan juga dapat diartikan sebagai hasil kerja yang dicapai karyawan dalam lingkup pekerjaan atau jabatan yang menjadi tanggung jawab karyawan yang bersangkutan di lingkungan sebuah organisasi (Nawawi, 2006:66).

Peneliti menilai bahwa knowledge sharing merupakan metode yang paling relevan dan tepat untuk mempercepat alih ide dan alih teknologi yang ada. Dimana terjadi suatu proses dimana individu secara kolektif dan interaktif memperbaiki sebuah pemikiran, gagasan, atau saran sesuai dengan petunjuk dari pengalaman individu lain secara efektif dan efisien baik pengetahuan tacit maupun explicit. Firmaiansyah (2014:135) mengemukakan bahwa terdapat pengaruh positif dan signifikan terhadap inovasi yang berarti bahwa semakin tinggi knowledge sharingmaka meningkatkan inovasi karyawan.

Pabrik Gula Jatiroto sebagai sebagai suatu perusahaan yang berhadapan langsung kepada stakeholder, memiliki pengelolaan padat karya dengan jumlah karyawan yang cukup tinggi. Hal ini berpotensi membuat pemahaman tentang sistem manajemen mutu akan berbeda di tiap lininya. Hasil penilaian kinerja belum secara optimal ditindaklanjuti oleh manajemen. Hal tersebut bisa dilihat karena masih terdapatnya kekecewaan pelanggan terhadap pelayanan administrasi dan keuangan, masih adanya karyawan yang belum pernah diikutsertakan dalam pelatihan di bidang yang dilakukannya, sehingga kompetensi karyawan masih perlu untuk ditingkatkan. Demikian juga halnya dengan fasilitas, sarana kerja dan dukungan organisasi sebagai infrastruktur pendukung kelancaran pelaksanaan pekerjaan juga masih perluditingkatkan.

Berdasarkan uraian-uraian dan fenomena-fenomena yang terjadi, dengan pertimbangan hampir homogennya karakteristik pekerjaan di Pabrik Gula Jatiroto serta relatif luasnya karakter lingkungan, maka peneliti mengangkat penelitian dengan judul Analisis Pengaruh Knowledge Sharing dalam Penerapan Sistem Manajemen Mutu ISO 9001:2008 terhadap Kinerja Inovasi dan Kinerja Karyawan pada Pabrik Gula Jatiroto.

Penelitian ini merumuskan masalah sebagai berikut: 1) Apakah knowledge 
sharing berpengaruh signifikan terhadap penerapan ISO 9001:2008?; 2) Apakah penerapan ISO 9001:2008 berpengaruh signifikan terhadap kinerja inovasi?; 3) Apakah knowledge sharing berpengaruh signifikan terhadap kinerja inovasi?; 4) Apakah penerapan ISO 9001:2008 berpengaruh signifikan terhadap kinerja karyawan?; 5) Apakah knowledge sharing berpengaruh signifikan terhadap kinerja karyawan?; 6) Apakah terdapat pengaruh tidak langsung yang signifikan antara knowledge sharing terhadap kinerja inovasi melalui penerapan ISO 9001:2008?; 7) Apakah terdapat pengaruh tidak langsung yang signifikan antara knowledge sharing terhadap kinerja karyawan melalui penerapan ISO 9001:2008?

Tujuan penelitian ini adalah untuk menguji dan membahas mengenai pengaruh antar variabel yang terdapat pada rumusan masalah.

\section{Knowledge Sharing}

Menurut Lumbantobing (2011:59), knowledge sharing sudah mencakup pengertian knowledge transfer yang diartikan sebagai proses sistematis dalam mengirimkan, mendistribusikan serta mendiseminasikan pengetahuan dan konteks multidimensi dari seorang atau organisasi kepada orang atau organisasi lainnya yang membutuhkan, melalui metoda dan media yang variatif.

Hoof dan Ridder (2004:31) memberikan pemahaman mengenai knowledge sharing sebagai proses dimana para individu secara mutual mempertukarkan pengetahuan mereka (baik pengetahuan tacit dan explicit), yang pada akhirnya secara terpadu dapat menciptakan pengetahuan baru. Knowledge sharing merupakan suatu proses saling berbagi pengetahuan baik antar individu maupun organisasi, untuk menciptakan tujuan bersama bagi organisasi yang ingin menggunakan aset pengetahuan mereka untuk mencapai keunggulan kompetitif. Knowledge sharing bisa berupa pengetahuan tacit dan explicit. Tacit merupakan pengetahuan yang masih tersembunyi, yang belum dibagikan kepada orang lain, yang diperoleh dari sensemaking, pengalaman, dan sebagainya. Sedangkan pengetahuan eksplisit merupakan pengetahuan yang sudah dibagi, dikomunikasikan, dan diketahui oleh orang lain.

\section{Sistem Manajemen Mutu ISO 9001:2008}

ISO 9001:2008 adalah suatu standar internasional untuk sistem manajemen mutu. ISO 9001:2008 menetapkan persyaratanpersyaratan dan rekomendasi untuk desain dan penilaian dari suatu sistem manajemen mutu, yang bertujuan untuk menjamin bahwa organisasi akan memberikan produk (barang atau jasa) yang memenuhi persyaratan yang ditetapkan. Sistem manajemen mutu ISO 9001:2008 berfokus pada proses dan pelanggan, oleh karena itu pemahaman terhadap persyaratan-persyaratan dari ISO 9001:2008 ini akan membantu organisasi dalam menetapkan dan mengembangkan sistem manajemen mutu secara sistematik untuk memenuhi kepuasan pelanggan (customer satisfaction) dan peningkatan proses terus-menerus (continious process improvement) (Gaspersz, 2005:62).

Kontraktor yang ingin mendapatkan sertifikat ISO 9001:2008 dapat mengikuti langkahlangkah yang secara garis besar sebagai berikut: (a) Adanya komitmen dari pimpinan puncak; (b) Membentuk komite pengarah atau Management Representative; (c) Mempelajari persyaratan-persyaratan standar dari sistem manajemen kualitas ISO 9001:2008; (d) Mengimplementasikan sistem manajemen kualitas ISO 9001:2008.

\section{Kinerja Inovasi}

Prakosa (2005: 49) menyatakan bahwa inovasi merupakan suatu cara untuk membangun dan mengembangkan organisasi secara terus menerus, yang dapat dicapai melalui introduksi teknologi baru, aplikasi baru dalam bentuk produk-produk dan pelayanan-pelayanan, pengembangan pasar baru dan memperkenalkan bentuk-bentuk baru organisasi, serta perpaduan berbagai aspek inovasi tersebut yang pada gilirannya membentuk arena inovasi. 
Menurut Rogers (2003:269) inovasi dapat ditunjang oleh beberapa faktor pendukung seperti: 1) Adanya keinginan untuk merubah diri, dari tidak bisa menjadi bisa dan dari tidak tahu menjadi tahu; 2) Adanya kebebasan untuk berekspresi; 3) Adanya pembimbing yang berwawasan luas dan kreaktif; 4) Tersedianya sarana dan prasarana; 5) Kondisi lingkungan yang harmonis. Dari hal tersebut dapat disimpulkan bahwa inovasi adalah modifikasi atau penemuan ide untuk perbaikan secara terus-menerus serta pengembangan untuk memenuhi kebutuhan pelanggan. Inovasi juga merupakan proses menciptakan ide baru, yang berbeda dari sebelumnya, dengan membuatnya menjadi nyata, dimana inovasi termasuk generasi evaluasi, konsep baru dan implementasi. Berdasarkan OECD Oslo Manual (2005), terdapat empat jenis inovasi yang berbeda, diantaranya: inovasi produk, inovasi proses, inovasi pemasaran dan inovasi organisasi.

\section{Kinerja Karyawan}

Kinerja karyawan adalah suatu hasil yang dicapai oleh karyawan tersebut dalam pekerjaanya berdasar kriteria tertentu yang berlaku pada suatu pekerjaan tertentu. Gibson (1997:84) mendefinisikan kinerja sebagai hasil dari pekerjaan yang terkait dengan tujuan organisasi seperti, kualitas, efesiensi, dan kriteria efektifitas lainya. Sedangkan menurut Robbins (2003:135) , kinerja karyawan merupakan fungsi antara kemampuan dan motivasi. Dalam studi manajemen kinerja, pekerja atau karyawan terdapat hal yang memerlukan pertimbangan penting, karena kinerja individual seorang karyawan dalam organisasi merupakan bagian dari kinerja organisasi yang dapat menentukan kinerja dari organisasi tersebut. Berhasil tidaknya kinerja karyawan yang telah dicapai organisasi tersebut akan dipengaruhi oleh tingkat kinerja dari karyawan secara individu maupun kelompok.

\section{METODE}

Penelitian ini menggunakan pendekatan kuantitatif explanatory dengan tujuan menguji dan membahas pengaruh knowledge sharing dalam penerapan sistem manajemen mutu ISO 9001:2008 terhadap kinerja inovasi dan kinerja karyawan pada Pabrik Gula Jatiroto, Kabupaten Lumajang, Provinsi Jawa Timur. Kajian dilakukan terhadap pengaruh langsung maupun tidak langsung antar variabel. Data diperoleh melalui pengisian kuesioner terhadap 130 responden yang dipilih dengan teknik proportional stratified random sampling berdasarkan golongan dengan rumus Slovin. Populasi yang diteliti merupakan karyawan tetap di Pabrik Gula Jatiroto pada 5 bagian yaitu: Tanaman, Teknik, Pengolahan, AKU, dan Quality Control dengan jumlah sebesar 193 orang. Karyawan tersebut dipilih berdasarkan kriteria yang sudah bekerja minimal 3 tahun. Dengan jumlah populasi 193 orang dan toleransi kesalahan 5\%, maka jumlah sampel ditetapkan sebesar 130 dengan $(n=\mathrm{N} /(1+$ $\left.\mathrm{N}^{2}\right)=193 /\left(1+193 \times 0,05^{2}\right)=$ $130,19 \approx 130$ ).

Variabel yang dianalisis sebagai berikut:

a. Variabel Eksogen adalah Knowledge Sharing (X).

b. Variabel Intervening dalah Penerapan ISO 9001:2008 (Z).

c. Variabel Endogen adalah kinerja inovasi $\left(\mathrm{Y}_{1}\right)$ dan kinerja karyawan $\left(\mathrm{Y}_{2}\right)$.

Pengumpulan data dalam penelitian ini berupa kuesioner berbentuk Skala Likert berisi data deskriptif maupun persepsi responden. Selain itu juga digunakan data sekunder berupa data karyawan. Analisis data dilakukan dengan teknik Structural Equation Modelling (SEM) menggunakan program software AMOS (Analysis of Moment Structure) 16.0. Penelitian dilakukan di Pabrik Gula Jatiroto, Kabupaten Lumajang, Propinsi Jawa Timur, sementara pengumpulan data dilaksanakan pada bulan Maret-Mei 2017.

\section{Uji Validitas Dan Reliabilitas}

Uji validitas dilakukan dengan menggunakan analisis faktor konfirmatori (confirmatory faktor analysis) pada masingmasing variabel laten. Masing-masing indikator yang digunakan dalam variabel 
penelitian ini menunjukkan nilai loading factor yang lebih besar dari 0,50. Hal ini berarti indikator-indikator yang digunakan dalam variabel penelitian ini layak atau valid digunakan sebagai pengumpul data.

Penghitungan reliabilitas menggunakan composite (contruct) reliability dengan cut off value minimal 0,70. Masing-masing variabel laten yang digunakan dalam penelitian ini memberikan nilai CR di atas nilai cut-off-nya sebesar 0,7. Sehingga dapat dikatakan masing-masing variabel laten dalam penelitian ini reliabel.

\section{Uji Asumsi Structural Equation Modelling}

Hasil pengujian normalitas diperoleh nilai critical ratio sebesar 1,574 yang berada diantara -2,58 sampai dengan 2,58, sehingga dapat dinyatakan bahwa data multivariate normal. Selain itu data univariat normal ditunjukkan oleh semua nilai critical ratio semua indikator terletak diantara $-2,58 \leq \mathrm{CR}$ $\leq 2,58$.

Sedangkan hasil pengujian multikolinieritas memberikan nilai determinant of sample covariance matrix sebesar 41,503. Nilai ini tersebut jauh di atas angka nol . Hal ini menunjukkan tidak terdapat masalah multikolinieritas dan singularitas pada data yang dianalisis.Hasil uji outliers dalam penelitian ini menunjukkan besarnya nilai Mahalanobis $d$-squared lebih kecil dari nilai Chi Square pada $(21 ; 0,01)$ yaitu sebesar 38,932. Hal ini menunjukkan dalam penelitian ini semua kasus tidak mengalami outliers atau dapat dikatakan tidak ada perbedaan yang signifikan antara data dengan kelompok data.

\section{HASIL DAN PEMBAHASAN \\ Hasil}

\section{Analisis Structural Equation Modelling}

Hasil pengujian dengan program AMOS memberikan hasil model SEM yang menunjukkan pengaruh knowledge sharing dalam Penerapan Sistem Manajemen Mutu ISO 9001:2008 terhadap kinerja inovasi dan kinerja karyawan pada Pabrik Gula Jatiroto. Meskipun hasil uji kesesuaian model (goodness of fit test) menunjukkan bahwa dari delapan kriteria terdapat salah satu kriteria masuk dalam kategori marginal, tetapi model tersebut masih dapat diterima. Hal ini mengacu pada pendapat Solimun (2002) yang menyatakan berdasarkan aturan parsimony jika sebagian besar kriteria fit model terpenuhi maka model telah dinyatakan fit. Dari berbagai indeks kesesuaian tersebut dapat disimpulkan bahwa model modifikasi yang diajukan sudah fit atau mempunyai kesesuaian yang cukup baik.

Tabel 1. Indeks Kesesuaian SEM

\begin{tabular}{lcc}
\hline \multicolumn{1}{c}{ Kriteria } & Nilai Cut Off & Hasil Pengujian \\
\hline Chi Square & $\mathbb{2}=154$ dengan $a=$ & 162,343 \\
Significance Probability & $\geq 05=183,959$ & 0,05 \\
RMSEA & $\leq 0,08$ & 0,020 \\
GFI & $\geq 0,90$ & 0,901 \\
AGF & $\geq 0,90$ & 0,852 \\
CMIN/DF & $\leq 2$ atau 3 & 1,054 \\
TL & $\geq 0,95$ & 0,989 \\
CFI & $\geq 0,95$ & 0,992
\end{tabular}

Sumber: data diolah

\section{Uji Hipotesis}

Hasil uji kausalitas menunjukkan bahwa terdapat pengaruh langsung yang signifikan antara variabel eksogen (X1) terhadap variabel perantara $(\mathrm{Z})$ dan kedua variabel endogen ( $\mathrm{Y} 1$ \& Y2), maupun antara variabel perantara terhadap kedua variabel endogen. Seluruh estimasi direct effect menunjukkan nilai $\mathrm{CR}>1,96$ dan nilai $\mathrm{P}<0,05$. Hal ini membuktikan bahwa H1, H2, H3, H4, danH5 terbukti secara signifikan. Nilai critical ratio dapat dilihat pada tabel regression weight berikut:

Tabel 2. Hasil Uji Kausalitas

\begin{tabular}{ccccccc}
\hline & & & Est & S.E. & C.R. & $P$ \\
\hline$Z$ & - & $X$ & 0.370 & 0.108 & 3.438 & $* * *$ \\
$Y 1$ & - & $X$ & 0.360 & 0.120 & 2.998 & 0.003 \\
$Y 2$ & $\leftarrow$ & $X$ & 0.598 & 0.196 & 3.045 & 0.002 \\
$Y 1$ & $\leftarrow$ & $Z$ & 0.949 & 0.263 & 3.608 & $* * *$ \\
$Y 2$ & - & $Z$ & 0.635 & 0.289 & 2.196 & 0.028 \\
\hline
\end{tabular}


Hasil besarnya pengaruh langsung dapat dilihat pada tabel Standardized Direct Effects berikut:

Tabel 3. Standardized Direct Effects

\begin{tabular}{ccccc}
\hline & $X$ & $Z$ & $Y 2$ & $Y 1$ \\
\hline$Z$ & 0.577 & 0.000 & 0.000 & 0.000 \\
$Y 2$ & 0.436 & 0.298 & 0.000 & 0.000 \\
Y1 & 0.395 & 0.669 & 0.000 & 0.000 \\
\hline
\end{tabular}

Sumber: data diolah

Hasil uji kausalitas juga menunjukkan adanya pengaruh tidak langsung yang signifikan dari variabel eksogen terhadap variabel endogen 1 (Y1) melalui variabel perantara, namun tidak ada pengaruh tidak langsung yang signifkan dari variabel eksogen terhadap variabel endogen 2 (Y2) melalui variabel perantara.

Besar pengaruh tidak langsung (indirect effect) dihitung berdasarkan nilai pada standardized indirect effect untuk interpretasi, akan tetapi untuk uji hipotesis harus menggunakan regression weight, karena pada statistik inilah tercantum standard error. Besar pengaruh tersebut dapat diketahui dengan mengalikan nilai estimate pada kedua jalur, dan dapat dilihat pada tabel Standardized Indirect Effects. Signifikansi besar pengaruh tidak langsung dihitung secara manual karena AMOS 16.0 yang digunakan sebagai software statistik dalam penelitian ini tidak menyediakan output untuk menentukan signifikansi pengaruh tidak langsung. Penghitungan signifikansi pengaruh tidak langsung dilakukan dengan Sobel Test (Hayes, 2013:719).

Tabel 4. Standardized Indirect Effects

\begin{tabular}{ccccc}
\hline & $X$ & $Z$ & $Y 2$ & $Y 1$ \\
\hline$Z$ & 0.000 & 0.000 & 0.000 & 0.000 \\
$Y 2$ & 0.172 & 0.000 & 0.000 & 0.000 \\
$Y 1$ & 0.386 & 0.000 & 0.000 & 0.000 \\
\multicolumn{4}{l}{ Sumber: data diolah }
\end{tabular}

Berdasarkan tabel Standardized Indirect Effects, besar pengaruh tidak langsung kedua variabel $(\mathrm{Y} 1 \leftarrow \mathrm{X})$ sebesar 0,368. Berdasarkan uji Sobel, diperoleh nilai $\mathrm{z}=$ 2,484 (> 1,96)menandakan bahwa terdapat pengaruh tidak langsung yang signifikan dari Knowledge Sharing terhadap Kinerja Inovasi di Pabrik Gula Jatiroto melalui mediasi Penerapan ISO 9001:2008.

Berdasarkan tabel Standardized Indirect Effects, besar pengaruh tidak langsung kedua variabel $(\mathrm{Y} 2 \leftarrow \mathrm{X})$ sebesar 0,172 . Berdasarkan uji Sobel, diperoleh nilai $\mathrm{z}=$ 1,85 $(<1,96)$ menandakan bahwa tidak terdapat pengaruh tidak langsung yang signifikan dari Knowledge Sharing terhadap Kinerja Karyawan di Pabrik Gula Jatiroto melalui mediasi Penerapan ISO 9001:2008.

Pengaruh total merupakan pengaruh yang disebabkan oleh adanya berbagai hubungan antar variabel baik langsung maupun tidak langsung. Pengaruh total dari variabel knowledge sharing bernilai positif baik terhadap penerapan ISO 9001:2008, kinerja inovasi maupun kinerja karyawan. Begitu juga untuk pengaruh langsung dari variabel penerapan ISO 9001:2008 terhadap kinerja inovasi dan kinerja karyawan. Besar pengaruh total dapat diketahui dari tabel Standardized Total Effects.

Tabel 5. Standardized Total Effects

\begin{tabular}{rcccc}
\hline & $X$ & $Z$ & $Y 2$ & $Y 1$ \\
\hline$Z$ & 0.577 & 0.000 & 0.000 & 0.000 \\
$Y 2$ & 0.608 & 0.298 & 0.000 & 0.000 \\
$Y 1$ & 0.781 & 0.669 & 0.000 & 0.000 \\
\hline
\end{tabular}

Sumber: data diolah

\section{Pengaruh Knowledge Sharing terhadap Penerapan ISO 9001:2008}

Hasil analisis data menunjukkan bahwa knowledge sharing mempunyai pengaruh yang signifikan terhadap penerapan ISO 9001:2008, sehingga hipotesis yang diajukan terbukti kebenarannya atau $\mathrm{H}_{1}$ diterima. Hasil penelitian ini sejalan dengan yang dilakukan oleh Rino dkk. (2012:64-84) dalam kaitannya dengan pemanfaatan teknologi informasi untuk memfasilitasi karyawan bertukar pengetahuan. Dalam penelitian ini belum 
mencakup dokumentasi terkait prosedur dan instruksi kerja dengan menyesuaikan standar manajemen mutu ISO 9001:2008. Knowledge sharing tersebut ditunjukkan dengan adanya proses penyampaian budaya dan visi misi perusahaan, perilaku karyawan, memberikan motivasi dan peluang secara adil, dan integrasi komunikasi antar bagian.

\section{Pengaruh Penerapan ISO 9001:2008 terhadap Kinerja Inovasi}

Hasil analisis data menunjukkan bahwa penerapan ISO 9001:2008 mempunyai pengaruh yang signifikan terhadap kinerja inovasi, sehingga hipotesis yang diajukan terbukti kebenarannya atau $\mathrm{H}_{2}$ diterima. Hasil penelitian ini sesuai dengan yang dilakukan oleh Zakiyah (2005:20) bahwa dengan menerapkan ISO 9001:2008 secara konsisten akan memacu organisasi untuk memberikan produk/ jasa, output organisasi atau sumber keuntungan yang lebih baik dari pesaingnya. Penerapan ISO 9001:2008 dapat dilihat melalui beberapa hal yaitu : perusahaan melakukan identifikasi aspek kualitas, perusahaan melakukan dokumentasi yang berkaitan dengan kualitas produksi, perusahaan melakukan training bagi karyawan dalam kaitan dengan kualitas produksi, adanya pembuatan prosedur standar kualitas produksi, adanya komitmen dari manajemen menuju pengembangan dan peningkatan sistem manajemen mutu.

\section{Pengaruh Knowledge Sharing terhadap Kinerja Inovasi}

Hasil analisis data menunjukkan knowledge sharing mempunyai pengaruh yang signifikan terhadap kinerja inovasi, sehingga hipotesis yang diajukan terbukti kebenarannya atau $\mathrm{H}_{3}$ diterima. Penelitian ini didasarkan pada pendapat dari penelitian sebelumnya Firmaiansyah (2014:135) yaitu bahwa terdapat pengaruh positif dan signifikan terhadap inovasi Lebih jauh bahwa hasil penelitian sejalan dengan Wang dkk.(2012:8899-8908) bahwa explicit knowledge sharing memiliki efek lebih signifikan pada kecepatan inovasi, sementara tacitknowledge sharing memiliki efek lebih signifikan pada kualitas inovasi. Aulawi dkk. (2009:174-187) memberikan gambaran bahwa tacit knowledge sharing berpengaruh positif terhadap peningkatan kemampuan inovasi individu utamanya dalam bentuk informal yang paling efektif. Knowledge sharing mampu meningkatkan kapabilitas inovasi dan keunggulan bersaing produk baru bagi perusahaan yang menggunakan teknologi tinggi.

\section{Pengaruh Penerapan ISO 9001:2008 terhadap Kinerja Karyawan}

Hasil analisis data menunjukkan penerapan ISO 9001:2008 mempunyai pengaruh yang signifikan terhadap kinerja karyawan, sehingga hipotesis yang diajukan terbukti kebenarannya atau $\mathrm{H}_{4}$ diterima. Hasil penelitian mendukung yang dilakukan oleh Pamungkas (2015). Penerapan ISO 9001: 2008 memiliki dampak positif dalam upaya untuk meningkatkan kinerja karyawan dengan kepedulian dan lingkungan kerja yang kondusif (Purba dkk. 2014:58-63). Penelitian ini berbeda dengan pendapat Aziz (2009:72) bahwa Sistem Manajemen Mutu ISO 9001:2008 tidak berpengaruh terhadap kinerja karyawan, namun dengan menggunakan pendekatan variabel yang berbeda yaitu faktor kompetensi, kesadaran dan pelatihan, infrastruktur dan lingkungan kerja.

\section{Pengaruh Knowledge Sharing terhadap Kinerja Karyawan \\ Hasil analisis data menunjukkan} knowledge sharing mempunyai pengaruh yang signifikan terhadap kinerja karyawan, sehingga hipotesis yang diajukan terbukti kebenarannya atau $\mathrm{H}_{5}$ diterima. Hasil penelitian sejalan dengan pendapat yang dikemukakan oleh Firmaiansyah (2014:135) dengan memasukkan kepuasan kerja sebagai salah satu variabelnya. Dalam konsep manajemen, manusia sebagai sumber daya dalam perusahaan/ instansi diharapkan mampu untuk memanfaatkan dan meningkatkan tenaga sepenuhnya atau seoptimal mungkin untuk meningkatkan produktifitas yang diikuti oleh terciptanya 
hubungan kerja yang bermutu dengan konotasi yang menyenangkan, penuh tenggang rasa dan saling membangun (Samuel dan Zulkarnain, 2012:6).

\section{Pengaruh Knowledge Sharing melalui Penerapan ISO 9001:2008 terhadap Kinerja Inovasi}

Hasil analisis data menunjukkan bahwa penerapan ISO 9001:2008 berperan secara signifikan sebagai mediator dalam pengaruh tidak langsung knowledge sharing terhadap kinerja inovasi, sehingga hipotesis yang diajukan terbukti kebenarannya atau $\mathrm{H}_{6}$ diterima. Dengan demikian, dapat disimpulkan bahwa meskipun koefisien direct effect menunjukkan kekuatan pengaruh yang lebih besar dibanding koefisien indirect effect, namun tinggi-rendahnya tingkat penerapan ISO 9001:2008 dapat secara nyata mempengaruhi seberapa efektif knowledge sharing membangun tingkat kinerja inovasi.

\section{Pengaruh Knowledge Sharing melalui Penerapan ISO 9001:2008 terhadap Kinerja Karyawan}

Hasil analisis data menunjukkan bahwa penerapan ISO 9001:2008 tidak berperan secara signifikan sebagai mediator dalam pengaruh tak langsung knowledge sharing terhadap kinerja karyawan, sehingga hipotesis yang diajukan tidak terbukti kebenarannya atau $\mathrm{H}_{7}$ ditolak. Dengan demikian, dapat disimpulkan bahwa tinggirendahnya tingkat penerapan ISO 9001:2008 tidak secara nyata mempengaruhi seberapa efektif knowledge sharing dalam membangun tingkat kinerja karyawan.

\section{Pembahasan}

Penelitian ini mencakup 7 hipotesis dengan membandingkan pengaruh langsung maupun tidak langsung dari setiap variabelnya diantaranya: (H1) Knowledge sharing berpengaruh terhadap penerapan ISO 9001:2008; (H2) Penerapan ISO 9001:2008 berpengaruh terhadap kinerja inovasi; (H3) Knowledge sharing berpengaruh terhadap kinerja inovasi; (H4) Penerapan ISO 9001:2008 berpengaruh terhadap kinerja karyawan; (H5) Knowledge sharing berpengaruh terhadap kinerja karyawan; (H6) Knowledge sharing berpengaruh tidak langsung terhadap kinerja inovasi melalui penerapan ISO 9001:2008; (H7) Knowledge sharing berpengaruh tidak langsung terhadap kinerja karyawan melalui penerapan ISO 9001:2008. Model penelitian digambarkan sebagai berikut:

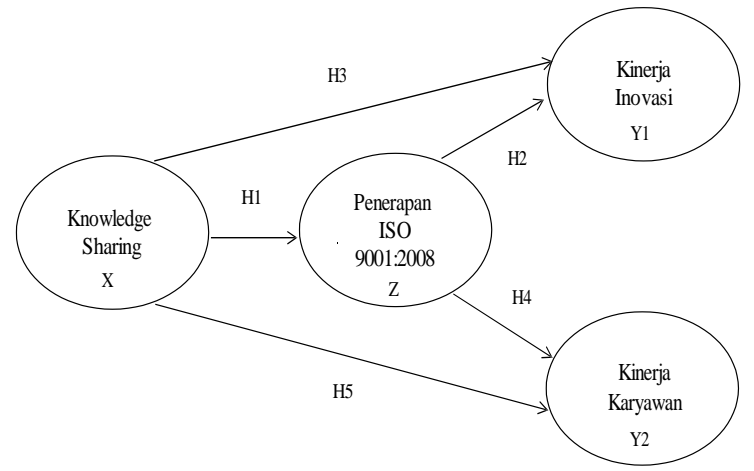

Gambar 1. Kerangka Konseptual Sumber: data diolah

Hipotesis pertama menunjukkan bahwa knowledge sharing mempunyai pengaruh yang signifikan terhadap penerapan ISO 9001:2008, sehingga hipotesis yang diajukan terbukti kebenarannya atau $\mathrm{H}_{1}$ diterima. Hal ini ditunjukkan dengan hasil pengujian koefisien jalur untuk pengaruh knowledge sharing (X) terhadap penerapan ISO 9001:2008 (Z) memiliki jalur positif sebesar 0,370 dengan C.R sebesar 3,438 dan probabilitas (p) sebesar 0,000. Hasil penelitian ini sejalan dengan yang dilakukan oleh Rino dkk. (2012:64-84) dalam kaitannya dengan pemanfaatan teknologi informasi yang memfasilitasi karyawan untuk bertukar pengetahuan. Selain itu penelitian ini sejalan menurut artikel dari http://suarakoridor.blogspot.co.id bahwa untuk melaksanakan prosedur dengan mendokumentasikan instruksi kerja yang disesuaikan dengan ISO 9001:2008, maka dibutuhkan suatu sistem kerja dalam rangkaian proses dari knowledge management. Knowledge sharing adalah suatu proses dimana individu secara kolektif dan interaktif memperbaiki sebuah pemikiran, gagasan, atau saran sesuai dengan petunjuk dari pengalaman individu (West dan 
Mayer, 1997:22).

Hipotesis kedua menunjukkan bahwa penerapan ISO 9001:2008 mempunyai pengaruh yang signifikan terhadap kinerja inovasi, sehingga hipotesis yang diajukan terbukti kebenarannya atau $\mathrm{H}_{2}$ diterima. Hal ini ditunjukkan melalui hasil pengujian koefisien jalur untuk pengaruh penerapan ISO 9001:2008 (Z) terhadap kinerja inovasi (Y1) memiliki jalur positif sebesar 0,949 dengan C.R sebesar 3,608 dan probabilitas (p) sebesar 0,000 . Hasil penelitian ini sesuai dengan yang dilakukan oleh Zakiyah (2005:20) bahwa dengan menerapkan ISO 9001:2008 secara konsisten akan memacu organisasi untuk menghasilkan produk/ jasa, output organisasi atau sumber keuntungan yang lebih baik dari pesaingnya. Dalam penelitian ini tidak didasarkan pada variabel kepemimpinan dan informasi seperti yang dilakukan oleh Hadiati (2007:144-154), sehingga tidak bisa diketahui pengaruh penerapan ISO 9001:2008 terhadap keunggulan bersaing melalui proses bisnis internal. Menurut Gaspersz (2001:62), dengan adanya penerapan ISO 9001:2008 yang konsisten dapat meningkatkan kepercayaan dan kepuasan pelanggan melalui jaminan mutu yang terorganisir dan sistematik.

Hipotesis ketiga menunjukkan knowledge sharing mempunyai pengaruh yang signifikan terhadap kinerja inovasi, sehingga hipotesis yang diajukan terbukti kebenarannya atau $\mathrm{H}_{3}$ diterima. Hal ini ditunjukkan melalui hasil pengujian koefisien jalur untuk pengaruh knowledge sharing (X) terhadap kinerja inovasi ( $\left.\mathrm{Y}_{1}\right)$ memiliki jalur positif sebesar 0,360 dengan C.R sebesar 2,998 dan probabilitas (p) sebesar 0,003. Penelitian ini sesuai dengan pendapat dari penelitian sebelumnya Firmaiansyah (2014:135) yaitu terdapat pengaruh positif dan signifikan knowledge sharing terhadap inovasi. Lebih jauh bahwa hasil penelitian sejalan dengan Wang dkk. (2012:8899-8908) bahwa explicit knowledge sharing memiliki efek lebih signifikan pada kecepatan inovasi, sementara tacit knowledge sharing memiliki efek lebih signifikan pada kualitas inovasi.
Penelitian ini mendukung yang dilakukan oleh Aulawi dkk. (2009:174-187) bahwa knowledge sharing berpengaruh positif terhadap peningkatan kinerja inovasi individu dalam penggunaan teknologi informasi.

Hipotesis keempat menunjukkan penerapan ISO 9001:2008 mempunyai pengaruh yang signifikan terhadap kinerja karyawan, sehingga hipotesis yang diajukan terbukti kebenarannya atau $\mathrm{H}_{4}$ diterima. Hal ini ditunjukkan melalui hasil pengujian koefisien jalur untuk pengaruh penerapan ISO 9001:2008 (Z) terhadap kinerja karyawan $\left(\mathrm{Y}_{2}\right)$ memiliki jalur positif sebesar 0,635 dengan C.R sebesar 2,196 dan probabilitas (p) sebesar 0,028. Hasil penelitian mendukung yang dilakukan oleh Pamungkas (2015). Penerapan ISO 9001: 2008 memiliki dampak positif dalam upaya untuk meningkatkan kinerja karyawan dengan kepedulian dan lingkungan kerja yang kondusif (Purba dkk. 2014:58-63). Penelitian ini berbeda dengan pendapat Aziz (2009:72) bahwa ISO 9001:2008 tidak berpengaruh terhadap kinerja karyawan, namun dengan menggunakan pendekatan variabel yang berbeda yaitu faktor kompetensi, kesadaran dan pelatihan, infrastruktur dan lingkungan kerja.

Hipotesis kelima menunjukkan knowledge sharing mempunyai pengaruh yang signifikan terhadap kinerja karyawan, sehingga hipotesis yang diajukan terbukti kebenarannya atau $\mathrm{H}_{5}$ diterima. Hal ini ditunjukkan dengan hasil pengujian koefisien jalur untuk pengaruh knowledge sharing (X) terhadap kinerja karyawan ( $\left.\mathrm{Y}_{2}\right)$ memiliki jalur positif sebesar 0,598 dengan C.R sebesar 3,045 dan probabilitas (p) sebesar 0,002. Hasil penelitian sejalan dengan pendapat yang dikemukakan oleh Firmaiansyah (2014:135) dan Sun dan Chiou (2011) dengan memasukkan kepuasan kerja sebagai salah satu variabelnya. Perusahaan/ instansi diharapkan mampu untuk memanfaatkan dan meningkatkan tenaga sepenuhnya atau seoptimal mungkin untuk meningkatkan produktifitas yang diikuti oleh terciptanya hubungan kerja yang bermutu dengan konotasi yang menyenangkan, penuh 
tenggang rasa dan saling membangun (Samuel dan Zulkarnain, 2010:6).

Hipotesis keenam menunjukkan bahwa penerapan ISO 9001:2008 berperan secara signifikan sebagai mediator dalam pengaruh tidak langsung knowledge sharing terhadap kinerja inovasi, sehingga hipotesis yang diajukan terbukti kebenarannya atau $\mathrm{H}_{6}$ diterima. Hal ini berdasarkan perhitungan pada tabel regression weight, nilai $\mathrm{z}$ sobel test didapat sebesar 2,484, yang berarti $\mathrm{z}>$ 1,96 menandakan bahwa terdapat pengaruh tidak langsung yang signifikan dari Knowledge Sharing melalui mediasi Penerapan ISO 9001:2008 terhadap Kinerja Inovasi. Tinggi-rendahnya tingkat penerapan ISO 9001:2008 dapat secara nyata mempengaruhi seberapa efektif knowledge sharing membangun tingkat kinerja inovasi. Sejalan dengan studi yang dilakukan oleh Jang dkk. (2008) menyimpulkan bahwa pelaksanaan ISO 9000 secara langsung berdampak positif pada kinerja operasional dan secara tidak langsung pada dampak pasar. Menurut Rogers (2003:269) inovasi dapat ditunjang oleh beberapa faktor pendukung seperti: 1) Adanya keinginan untuk merubah diri, dari tidak bisa menjadi bisa dan dari tidak tahu menjadi tahu; 2) Adanya kebebasan untuk berekspresi; 3) Adanya pembimbing yang berwawasan luas dan kreaktif; 4) Tersedianya sarana dan prasarana; 5) Kondisi lingkungan yang harmonis. Untuk menjalankan hal tersebut, diperlukan pembuatan prosedur standar terhadap semua aktifitas kerja terhadap kualitas secara jelas dan mudah diterapkan (Samuel dan Zulkarnain, 2010:3-4).

Hipotesis ketujuh menunjukkan bahwa penerapan ISO 9001:2008 tidak berperan secara signifikan sebagai mediator dalam pengaruh tak langsung knowledge sharing terhadap kinerja karyawan, sehingga hipotesis yang diajukan tidak terbukti kebenarannya atau $\mathrm{H}_{7}$ ditolak. Hal ini berdasarkan perhitungan pada tabel regression weight, nilai $\mathrm{z}$ sobel test didapat sebesar 1,850. Dengan demikian, dapat disimpulkan bahwa tinggi-rendahnya tingkat penerapan ISO 9001:2008 tidak secara nyata mempengaruhi seberapa efektif knowledge sharing membangun tingkat kinerja karyawan. Walaupun penelitian terdahulu (Al-Refaie dkk., 2012) menunjukkan adanya keterkaitan antara penerapan ISO 9001:2008 terhadap peningkatan kinerja, namun penerapan ISO 9001:2008 bukan merupakan faktor yang esensial untuk menjembatani knowledge sharing untuk peningkatan kinerja karyawan. Berbeda dengan penelitian yang dilakukan oleh Aulawi dkk. (2009:174-187) jika tanpa mediasi dari penerapan ISO 9001:2008, knowledge sharing merupakan sisi bagian dari KPI (Key Performance Indicator) karyawan, serta pengembangan sistem reward bagi karyawan. Berbeda pendekatan dari penelitian oleh Kurnia (2011:72), yang memberikan kesimpulan bahwa tacit knowledge berpengaruh terhadap kinerja individu sebagai karyawan dengan menitikberatkan pada pengalaman, interaksi personal, komunitas dan kondisi lingkungan kerja.

\section{Keterbatasan Penelitian}

Dalam penelitian masih terdapat beberapa keterbatasan yang seharusnya masih dapat dieksplorasi lebih dalam diantaranya bahwa penerapan ISO 9001:2008 belum mencerminkan bagaimana kinerja perusahaan secara luas karena juga dipengaruhi faktor lain seperti kinerja keuangan ataupun kinerja pemasaran produk. Selain itu dalam penelitian ini belum disertakannya variabel moderator, misal demografi dan budaya individu dalam mengkaji pengaruh antar variabel. Hal ini tentu saja berbeda jika objek penelitian adalah Pabrik Gula baru dengan mesin peralatan modern.Penelitian ini juga belum melakukan perhitungan yang lebih luas terhadap variabel-variabel lain yang ikut memengaruhi variabel endogen, seperti bagaimana usia kerja dalam memengaruhi aplikasi knowledge sharing, juga cara pandang karyawan dalam menerima inovasi baru dengan memperhatikan masa kerja di Pabrik Gula Jatiroto. 


\section{Implikasi Manajerial}

Pabrik Gula Jatiroto mampu untuk menawarkan knowledge sharing yang berkelanjutan dan sistematik, sehingga mendorong penerapan ISO 9001:2008 secara menyeluruh. Hal tersebut dapat mendorong perusahaan untuk terus berkembang mengikuti permintaan stakeholder. Melalui penerapan sistem manajemen mutu, kinerja inovasi utamanya dalam hal perbaikan mutu produk dan jasa akan memiliki keunggulan bersaing dalam jangka panjang. Supaya pemahaman dapat berlangsung secara berkelanjutan dari tahun ke tahun, maka manajemen harus membiasakan diri untuk selalu melakukan proses dokumentasi melalui penerapan ISO 9001:2008 sehingga kebijakan, prosedur dan instruksi kerja yang berkaitan dengan mutu bisa direncanakan denganbaik. Proses tacit dan explicit knowledge sharing antar level hendaknya dilakukan secara periode berkala, sehingga ide, teknologi maupun dokumen pendukung dapat dipelajari oleh semua karyawan.

Pemberian motivasi kerja melalui meningkatkan kenyamanan dan kebermaknaan dalam bekerja, dibutuhkan agar karyawan dapat memberikan yang terbaik dari sisi pelayanan, komunikasi serta kinerja. Hal ini dapat meningkatkan mutu dan produktivitas dari manajemen melalui kerjasama dan komunikasi yang lebih baik, sistem pengendalian yang konsisten serta pengurangan dan pencegahan pemborosan, sehingga meningkatkan kesadaran mutu dalam perusahaan.

Sistem Manajemen Mutu ISO 9001 sebaiknya diupdate ke versi yang lebih baru yaitu ISO 9001:2015 agar lebih relevan dengan kebutuhan stakeholder, tentunya dengan perbaikan dokumen dan kebijakan sebagai persyaratan pelaksanaan resertifikasi. Pada tahun 2018 Pabrik Gula Jatiroto akan mengalami transformasi menjadi Pabrik Gula terbesar dan modern di Pulau Jawa, sehingga kinerja karyawan dari berbagai sisi menuntut untuk berkembang lebih baik.

\section{Kesimpulan}

Berdasarkan deskripsi, analisis hasil penelitian pada pembahasan, simpulan atas temuan penelitian adalah bahwa knowledge sharing berpengaruh signifikan terhadap penerapan ISO 9001:2008. Proses knowledge sharing berjalan secara terencana dan sistematis kaitannya dengan dokumentasi prosedur, instruksi kerja dan komitmen manajemen. Dengan menerapkan ISO 9001:2008 secara konsisten akan memacu organisasi untuk memberikan produk/ jasa, output organisasi atau sumber keuntungan yang lebih baik, sehingga dalam hal ini penerapan ISO 9001:2008 berpengaruh signifikan terhadap kinerja inovasi.

Perusahaan harus bisa memberikan inovasi kepada karyawan, proses knowledge sharing memberikan pengaruh yang signifikan terhadap kinerja inovasi. Melalui knowledge sharing oleh key user kepada karyawan pelaksana, membuat inovasi menjadi semakin beragam karena ide-ide muncul secara simultan. Dampak dari ide yang simultan, adalah peningkatan kinerja karyawan yang ditunjukkan dengan adanya disiplin kerja dalam waktu dan penggunaan alat kerja, pencapaian sasaran yang dicapai terhadap target, dan inisiatif atau kreativitas yang mempengaruhi pekerjaan, sehingga penerapan ISO 9001:2008 berpengaruh signifikan terhadap kinerja karyawan. Knowledge sharing berpengaruh signifikan terhadap kinerja karyawan karena knowledge sharing membuka kesempatan mengeksplorasi pengetahuan untuk mendapatkan atau menciptakan knowledge baru.

Penerapan ISO 9001:2008 berperan secara signifikan sebagai mediator dalam pengaruh tidak langsung knowledge sharing terhadap kinerja inovasi, namun penerapan ISO 9001:2008 tidak berperan secara signifikan sebagai mediator dalam pengaruh tak langsung knowledge sharing terhadap kinerja karyawan di Pabrik Gula Jatiroto.

Keterbataan yang dijumpai dalam penelitian ini masih dapat dieksplorasi lebih dalam, terutama untuk menambahkan variabel lain seperti demografi dan budaya 
individu dalam perusahaan, karena budaya yang dibawa oleh masing-masing individu dalam sebuah tim di perusahaan akan mempengaruhi kinerja karyawan dalam menerima sebuah inovasi baru melalui sebuah proses knowledge sharing. Hal tersebut agar mendapatkan kajian yang lebih komprehensif dan mendalam, mengenai fungsi knowledge sharing yang lebih menyeluruh dan berguna bagi pengembangan ilmu pengetahuan khususnya manajemen sumber daya manusia.

\section{DAFTAR PUSTAKA}

Al-Refaie, A. dan O. Ghnaimat. 2012. Effects of ISO 9001 Certification and KAAE on Performance of Jordanian Firms. Jordan Journal of Mechanical and Industrial Engineering. 6(1): 45-53.

Asosiasi Gula Indonesia. 2016. Produksi Gula Nasional. Jakarta: Published by PT Bank Mandiri.

Aulawi, H. dan R. Govindraju. 2009. Hubungan Knowledge Sharing Behavior dan Individual Innovation Capability. Jurnal Teknik Industri. 11(2): 174-178.

Aziz, Anhar. 2009. Pengaruh Penerapan Sistem Manajemen Mutu ISO 9001:2008 Terhadap Kinerja Pegawai Dengan Pemberian Insentif dan Kepuasan Kerja Sebagai Variabel Mederating di PT (Persero) Pelabuhan Indonesia.Tesis. Medan: Sekolah Pasca Sarjana Universitas Sumatera Utara.

Firmaiansyah, D. 2014. Pengaruh Berbagi Pengetahuan Terhadap Kinerja Karyawan Melalui Inovasi. Jurnal Ilmu Manajemen. 2(1): 128-139.

Gaspersz, V. 2005. Total Quality Management. Jakarta: Gramedia Pustaka Utama.

Gibson, J. S. dan M. John. 1997. Organisasi, Prilaku Struktur dan Proses. Edisi ke5. Jakarta: Erlangga.
Hadiati, S. 2007. Pengaruh Faktor-Faktor Manajemen Mutu Terpadu Terhadap Proses Bisnis Internal dan Keunggulan Bersaing Industri Manufaktur yang Memperoleh ISO 9000 Di Jawa Timur. Jurnal Manajemen dan Kewirausahaan. 9(2): 144-154.

Nasution. 2001. Entreprenuership Membangun Spirit Teknopreneurship. Yogyakarta: Andi.

Nawawi. H. 2003. Manajemen Sumber Daya Manusia Untuk Bisnis yang Kompetitif. Yogyakarta: Gadjah Mada University Press.

Hayes, A. F. 2013. Introduction to mediation, moderation, and conditional process analysis: a regression-based approach. New York: The Guilford Press.

Hooff, V.D., and Ridder, J.A. 2004. Knowledge Sharing in Context: The influence of Organizational Commitment, Communication Climate and CMC use on Knowledge Sharing. Journal of Knowledge Management. 11(1): 13-24.

Jang, W. Y. dan C. I. Lin. 2008. An Integrated Framework For ISO 9000 Motivation, Depth Of ISO Implementation And Firm Performance. The Case Of Taiwan. Journal of Manufacturing Technology Management. 19(2): 194-216.

Kurnia, N. 2011. Model Hubungan Tacit Knowledge Dan Kinerja Individu Pada Balai Riset Dan Standarisasi Industri. Skripsi. Jakarta: Universitas Indonesia.

Lumbantobing, Paul. 2011. Manajemen Knowledge Sharing Berbasis Komunitas, Knowledge Management Society Indonesia. Bandung.

OECD dan Eurostat. 2005. Oslo Manual: Guidelines for Collecting and Interpreting Innovation Data (3rd ed.). Paris: OECD Publishing. 
Pamungkas, S. Chandra. 2015. Pengaruh Penerapan ISO 9001:2008 Terhadap Kinerja Pegawai Sekretariat Daerah Pemerintahan Kota Malang. Artikel Tidak Dipublikasikan. Malang: Universitas Brawijaya.

Prakosa, B. 2005. Pengaruh Orientasi Pasar, Inovasi Dan Orientasi Pembelajaran Terhadap Kinerja Perusahaan Untuk Mencapai Keunggulan Bersaing (Studi Empiris Pada Industri Manufaktur Di Semarang). Jumal Studi Manajemen \& Organisasi. 2(1).

Purba, D. Tiur, dan S. Khawarita. 2014. Analisis Pengaruh Sistem Manajemen Mutu ISO 9001:2008 Terhadap Kinerja Karyawan Di PT. X. eJurnal Teknik Industri. FT USU 1(1):58-63

Robbins, S. P. 2003. Organizational Behavior.Ninth Edition. New Jersey : Prentice Hall International Inc.

Rogers, M,. 2003. Diffusions of Innovations, Forth Edition. New York: Tree Press.

Rino. 2012. Pengaruh Teknologi Informasi Smart Kampus, Implementasi Sistem Manajemen Mutu ISO 9001:2008 Dan Skill Kepemimpinan Terhadap Knowledge Management, Motivasi Kerja Dan Kinerja Dosen Universitas Negeri Padang. Artikel Tidak Dipublikasi. Padang: Universitas Negeri Padang.

Samuel, H dan J. Zulkarnain. 2012. Pengaruh Sistem Manajemen Mutu ISO Terhadap Kinerja Karyawan Melalui Budaya Kualitas Perusahaan. Jurnal Ilmu Manajemen. 4(2): 516-537.

Solimun. 2002. Multivariate Analysis Structural Equation Modelling (SEM) Lisrel dan Amos. Malang: Universitas Brawijaya.
Suara Koridor Mahasiswa. 2015. Penerapan Manajemen Pengetahuan pada PT. PLN Persero Ranting Malili dalam Rangka Memenuhi Kebutuhan Energi Listrik Masyarakat Modern. http://suara-koridor.blogspot.co.id. (Diakses pada 22 Februari 2017).

Sun, K. dan H. Chiou. 2011. Aviation Ground Crews: Occupational Stresses and Work Performance. African Journal of Business Management. 5(7): 2865-2873.

Wang, Z. dan N. Wang. 2012. Knowledge Sharing, Innovation and Firm Performance. Department of Human Resource Management, School of Management. Expert Systems with Applications. 39: 8899-8908.

West, P. dan Meyer. 1997. Communicated Knowledge As A Learning Foundation. International Journal of Organizational Analysis. 5(1): 25-58.

Zakiyah. 2005. Pertumbuhan Berkelanjutan Dengan Sistem Manajemen Mutu ISO 9000 : Upaya Peningkatan Daya Saing Industri. Artikel Tidak Dipublikasi. Bogor: Institut Pertanian Bogor. 